\title{
Environmental unpredictability rules the autumn migration of brown trout (Salmo trutta L.) in the Belgian Ardennes
}

\author{
M. Ovidio, E. Baras, D. Goffaux, C. Birtles \& J. C. Philippart \\ University of Liège, Laboratory of Fish Demography and Aquaculture, Chemin de la Justice, 10, B-4500 Tihange, \\ Belgium.E-Mail:M.Ovidio@ulg.ac.be;E.Baras@ulg.ac.be
}

Key words: spawning migration, temperature, flood, Salmo trutta, radio tracking, River Meuse Basin

\begin{abstract}
This telemetry study aimed to document the mobility of Salmo trutta in the River Ourthe sub-basin (tributary of the River Meuse) during summer and autumn, and to analyse the environmental factors which trigger spawning migration or limit their extension. Nine trout (233-2217 $\mathrm{g}$ and $26.6-55.2 \mathrm{~cm}$ FL) were radio-tagged with intraperitoneal radio transmitters and positioned daily, from 14 August 1996 to 15 January 1997. Until 1 October, fish showed restricted movements: daily journeys never exceeded $300 \mathrm{~m}$ and corresponded to displacements by high floods or to routine home range movements. From 7 October to 15 November, seven of the nine trout travelled upstream over distances from 5.6 to $22.95 \mathrm{~km}$, into tributaries and sub-tributaries. Migration speed was fast during the early days, when trout could travel over more than $5 \mathrm{~km}$ per night, then progressively decreased as they were approaching putative spawning redds under lower temperature. Both in the River Ourthe and in the Aisne stream, all migrations started within less than three weeks (early October) and were found to be triggered by the combination of three environmental factors: high variations of water temperature and water level between consecutive days, within a thermal range of $10-12{ }^{\circ} \mathrm{C}$. From the trout point's of view, these may be signs that the environment becomes unpredictable, as its variability increases within a thermal range which no longer enables them to achieve high growth rates. These results are discussed within the context of foraging strategies, life history strategies and management of trout population.
\end{abstract}

\section{Introduction}

The migration of trout Salmo trutta L. has been abundantly documented (Shetter, 1968; Solomon and Templeton, 1976; Harcup et al., 1984; Baglinière et al., 1987; Hesthagen, 1988; Jonsson, 1991). However, recent studies questioned the nature of restricted movements of brown trout and urged the need for a detailed and precise analysis of their space utilisation strategies at the individual level (Gowan et al., 1994; Fausch \& Young, 1995; Ovidio et al., 1998). This analysis at the individual level becomes more crucial during the spawning migrations, when mobility also corresponds to a flow of genes through the ecosystem (Philippart \& Baras, 1996) and when interferences with genuine mobility patterns may affect the structure of the population.
In Belgian waters, most trout populations have been deeply affected by restocking practices and by hydraulic works, which caused the extinction of most anadromous species or ecotypes, including the Atlantic salmon Salmo salar L. and the sea trout Salmo trutta trutta L. (Philippart, 1987; Philippart et al., 1988, 1994). In these ecosystems, there is a dearth of knowledge on the actual mobility patterns of trout, the location of their spawning redds in tributaries or sub-tributaries, and on their actual chances to access these, considering the potential impact of small weirs and dams which are often regarded as obstacles with no or minor effect. This study aimed to study the spawning migrations of trout in the Belgian Ardennes, focusing on the timing of spawning migrations, and on the role of environmental variables in triggering, enhancing or inhibiting the spawning migration of trout. 
These may represent key factors in the efficient management of rivers within the scope of ecohydraulic development (Leclerc et al., 1996). Considering the need for detailed information on trout movements, the study relied on the day-by-day location of individuals equipped with radio telemetry transmitters.

\section{Study area}

The River Ourthe is the main sub-basin of the River Meuse in Southern Belgium. It runs through the Belgium Ardennes where it meets typical salmonid tributaries such as the Amblève or Aisne streams (Figure 1). The study area was located in between the villages of Chanxhe (Ourthe) and Erezée (Aisne). This section is devoid of any major dam but contains small weirs, of less than $1 \mathrm{~m}$ in height, which are presumed to have little impact on the free circulation of trout (Figure 1). The R. Ourthe in this area has a mean slope of $1.5 \%$, a mean width and flow of $25 \mathrm{~m}$ and $32 \mathrm{~m}^{3} \mathrm{~s}^{-1}$, respectively. It is typical of the barbel and grayling zones and hosts a mixed cyprinid-salmonid fish assemblage of which the main constituents are: the barbel Barbus barbus (L.), chub Leuciscus cephalus (L.), nase Chondrostoma nasus (L.), grayling Thymallus thymallus (L.) and trout Salmo trutta (L.). The Aisne is a typical trout stream (slope $2.78 \%$, mean width and flow: $14 \mathrm{~m}$ and $2.41 \mathrm{~m}^{3} \mathrm{~s}^{-1}$ ) which meets the R. Ourthe in Bomal (Figure 1). The fish assemblage mainly consists of trout, grayling, sculpin Cottus gobio and stone loach Barbatula barbatula. The water temperature in the R. Ourthe and Aisne stream varies over the annual cycle, from $0{ }^{\circ} \mathrm{C}$ to $26{ }^{\circ} \mathrm{C}$ (mean: $10.5^{\circ} \mathrm{C}$ ), and from to $0{ }^{\circ} \mathrm{C}$ to $19{ }^{\circ} \mathrm{C}$ (mean: $9.4{ }^{\circ} \mathrm{C}$ ), respectively.

\section{Materials and methods}

In spring and summer 1996, trout were captured by electric fishing (EPMC, $2.5 \mathrm{kVA}$ ) or caught in a fish trap (controlled daily) at the weir of Bomal on the Aisne stream, $400 \mathrm{~m}$ upstream of the confluence with the R. Ourthe. All trout were tagged according to the methodology evaluated by Birtles et al. (1995). They were anaesthetised with a $0.25 \mathrm{ml} \mathrm{l}^{-1}$ solution of 2-phenoxy ethanol, then placed ventral side up into a v-shaped support adjusted to their morphology. A mid ventral incision was made between the pelvic girdle and the anus and an alcohol sterilised transmitter (40 MHz, internal coiled antenna; Table 1) was inserted into their body cavity. The weight of the transmitter ranged from 3.7 to $22.0 \mathrm{~g}$ depending on trout body weight, making sure that the transmitter to fish body weight ratio in the air would not exceed $2.0 \%$. The incision was closed by two or three separate stitches, $9-10 \mathrm{~mm}$ apart, using sterile plain catgut (2.0,3.0 or 4.0 Dec., depending on fish size) on cutting needles. Fish were released precisely at their capture site as soon as they had recovered posture and spontaneous swimming (about 3 min after surgery), in order to minimise possible biases originating from long term post operative care.

Fish were located at least once a day until the end of their transmitter battery life or latest until 15 January 1997, in order to document all movements during the spawning period. Locations were made by triangulation from markers on the rivers' banks, using a mobile FieldMaster radio receiver and a loop antenna (ATS). All locations were made during daytime, with an accuracy from 1 to $4 \mathrm{~m}^{2}$, depending on the distance between the fish and the observer. Net daily journeys were defined as the distance between diurnal locations at two consecutive days and were used to quantify migratory activity. The relationships between the mobility of trout and environmental variables were investigated by stepwise multiple regression analyses. In order to identify the key variables, we compared the relative frequency $(\%)$ of net daily journeys longer than the extension of the daily activity area $(30 \mathrm{~m})$ at the weekly level over 13 weeks, to the variations of day length, water temperature and level (mean, standard deviation, weekly and daily variation), using linear variables, semi-logarithmic and logarithmic transformates. The relevant variables were later categorised and tested with multiple analyses of variance to identify more precisely the sets of environmental conditions which favoured, enhanced or inhibited the migration of trout.

Temperature in the River Ourthe and Aisne stream was logged every $30 \mathrm{~min}$ on data loggers installed in Hamoir and Juzaine, respectively, with an accuracy of $0.1{ }^{\circ} \mathrm{C}$. Water levels were measured daily with an accuracy of $1 \mathrm{~cm}$, on limnimetric scales installed near the temperature loggers (Figure 1).

\section{Results}

\section{Aisne stream}

Trout in the Aisne stream showed contrasted mobility patterns depending on season. From mid-August to 

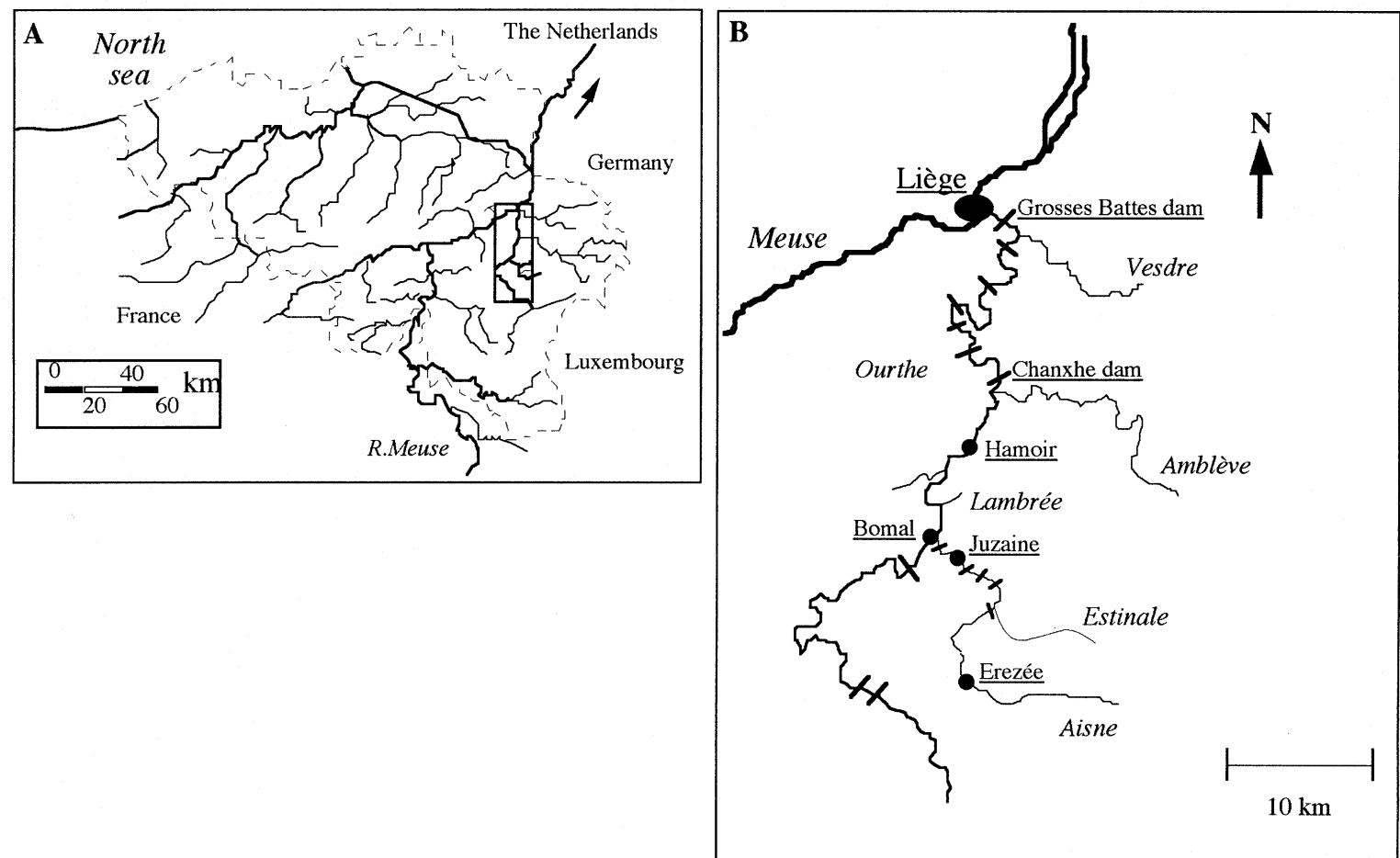

Figure 1. Location of the study area on the River Ourthe and the Aisne stream in Southern Belgium (Wallonie), in between Liège and Erezée. Transverse bars on the River Ourthe and on the Aisne stream on map B are weirs and dams which may interfere with the free circulation of fish.

Table 1. Characteristics of the radio-tagged trout in 1996. Fish code TA and TO stand for fish released in the Aisne stream and River Ourthe, respectively. TW and TBWR are the transmitter weight and transmitter to body weight ratio in the air. Trout captured in fish pass (FP) at weirs or by electric fishing $(\mathrm{EF})$. All fish released on the day of capture, except for TO2 (*)

\begin{tabular}{lllllllll}
\hline $\begin{array}{l}\text { Fish } \\
\text { code }\end{array}$ & $\begin{array}{l}\text { Length } \\
(\mathrm{FL}, \mathrm{cm})\end{array}$ & $\begin{array}{l}\text { Weight } \\
(\mathrm{g})\end{array}$ & Sex & $\begin{array}{l}\text { T W } \\
(\mathrm{g})\end{array}$ & $\begin{array}{l}\text { TBWR } \\
(\%)\end{array}$ & $\begin{array}{l}\text { Date of } \\
\text { capture }\end{array}$ & $\begin{array}{l}\text { Place, method } \\
\text { of capture }\end{array}$ & \\
\hline TA1 & 32.5 & 398 & $\mathrm{M}$ & 3.7 & 0.9 & 22 Apr & Bomal & FP \\
TA2 & 28.0 & 305 & $\mathrm{~F}$ ? & 3.7 & 1.2 & 14 Aug & Juzaine & EF \\
TA3 & 28.8 & 271 & & 3.7 & 1.4 & 14 Aug & Juzaine & EF \\
TA4 & 26.6 & 233 & & 3.7 & 1.6 & 14 Aug & Juzaine & EF \\
TA5 & 27.2 & 233 & M & 3.7 & 1.6 & 14 Aug & Juzaine & EF \\
TA6 & 29.5 & 287 & & 3.7 & 1.3 & 19 Sep & Bomal & EF \\
& & & & & & & & \\
TO1 & 43.8 & 1083 & & 12.5 & 1.1 & 08 May & Grosses Battes & EF \\
TO2 & 48.0 & 1550 & & 22.4 & 1.4 & 04 Jun & Chanxhe & EF* \\
TO3 & 55.2 & 2217 & M & 20.0 & 0.9 & 19 Sep & Chanxhe & EF \\
\hline
\end{tabular}


early October, they showed most restricted movements which never exceeded $300 \mathrm{~m}$. The longest movements were observed during a spate in late August, which coincided with a sudden summer rainstorm which raised the water level by $1 \mathrm{~m}$ and presumably displaced the trout from their residences (Figure 2). Trout A1, which was located downstream of the weir at Bomal consistently occupied this place during autumn and winter and made no migration, even when the weir could be cleared at any time under high flood. The five other trout in the Aisne stream made much more extensive upstream movements, which all started from early to mid-October 1996.

Trout A6, which occupied the most downstream position, upstream of Bomal's weir was the first fish to initiate its migration on 6 October. The four trout in Juzaine all started migrating within the same week: 14 October for TA2, 17 October for TA3 and 20 October for TA4 and TA5. TA3 was lost two days after it left its summer home range and had travelled more than $2.40 \mathrm{~km}$. All other trout were located daily and migrated over considerable distances compared to the length of the Aisne stream (app. $50 \mathrm{~km}$ ). Trout TA5 entered a sub-tributary, the Estinale stream, whereas all other trout remained within the Aisne stream. Small weirs in the Aisne stream (see Figure 1) sometimes caused short migration delays (maximum two days) but turned out to be cleared easily by the fish, at least under rising water levels: trout TA6 and TA5 cleared five weirs each, TA4 cleared four weirs and TA2 cleared two. The signals of TA4 and TA5 were lost in early November, when their battery failed. TA2 which had covered $5.2 \mathrm{~km}$ within 3 days, abruptly stopped moving whilst other fish were still migrating. Its transmitter was found lost on the gravel substratum in early December. TA6 also abruptly stopped migrating and was consistently located at the same place until the end of its transmitter battery life, in early December. Frequent walks in the stream in late November never caused any movement by the fish, which was presumed to have lost its transmitter as well. Transmitter losses in fish which normally have healed their incision may suggest a papilla exit at the time trout lay their eggs. This however could not be confirmed as high turbidity in the Aisne stream did prevent any direct observation of trout spawning during autumn.

TA6, 5, 4 and 2 travelled over $12.94 \mathrm{~km}$ within 13 days, $19.68 \mathrm{~km}$ within 22 days, $22.95 \mathrm{~km}$ within 13 days and $5.3 \mathrm{~km}$ within 3 days, respectively, corresponding to mean upstream progression speeds from 0.99 to $1.56 \mathrm{~km} \mathrm{~d}^{-1}$ (3373 to 5856 body length -
$\mathrm{BL}-\mathrm{d}^{-1}$ ). Migrating trout were not travelling continuously over 24 hours. Except for some small scale movements during daytime, the migration took place at night. Three net daily journeys were longer than $5.00 \mathrm{~km}(5.97 \mathrm{~km}$ for TA5; 5.98 and $7.20 \mathrm{~km}$ for TA4). Considering a mean nocturnal duration of 14 hours in mid-October, the mean upstream progression rate of trout during these long journeys ranged from 0.43 to $0.54 \mathrm{BL} \mathrm{s}^{-1}$. As the mean water velocity in the Aisne stream ranged from 30 to $50 \mathrm{~cm} \mathrm{~s}^{-1}$, depending on environment, trout TA5 and TA4 presumably had swimming speeds from 1.53 to $2.42 \mathrm{BL} \mathrm{s}^{-1}$ over the night.

Stepwise multiple-regression analyses indicated that mean water temperature, the amplitude of daily variations of water temperature and level (regardless of whether such variable were increasing or decreasing), were significantly correlated to the frequency of fish movements $(P=0.002,0.021$ and 0.053 , respectively). These three variables were categorised for a 3-way ANOVA over the length of net daily journeys (Table 2A). This analysis clearly indicates that trout show a significantly higher propension to migrate under varying water level and temperature between 10 and $12{ }^{\circ} \mathrm{C}$ than under any other set of environmental conditions. The comparison between the occurrence of this special set of environmental conditions throughout summer and autumn and the mobility of trout, indicates that this condition was fulfilled only three times before all trout started their migration (October 2, 3 and 20). TA6 left its summer home range on the first day when it happened and TA5 and TA4 together on the third occasion. TA2 started moving under similar thermal conditions, but under a stable water level. This finding substantiates the influence of environment variability on the propension of trout to migrate.

\section{River Ourthe}

As in the Aisne stream, all three trout showed restricted movements during summer and early autumn but were displaced downstream by summer high floods (Figure 3). TO1 consistently remained downstream of the Grosses Battes dam until mid-December, when the water temperature decreased down to $0{ }^{\circ} \mathrm{C}$. It left this place down to the River Meuse, which was 2 to $3{ }^{\circ} \mathrm{C}$ warmer but obviously made no spawning migration as no spawning areas are available in the R. Meuse. TO2 made an early $2 \mathrm{~km}$ upstream movement on 11 October then resumed its upstream migration on 22 October, after TO3 had arrived in this place. 


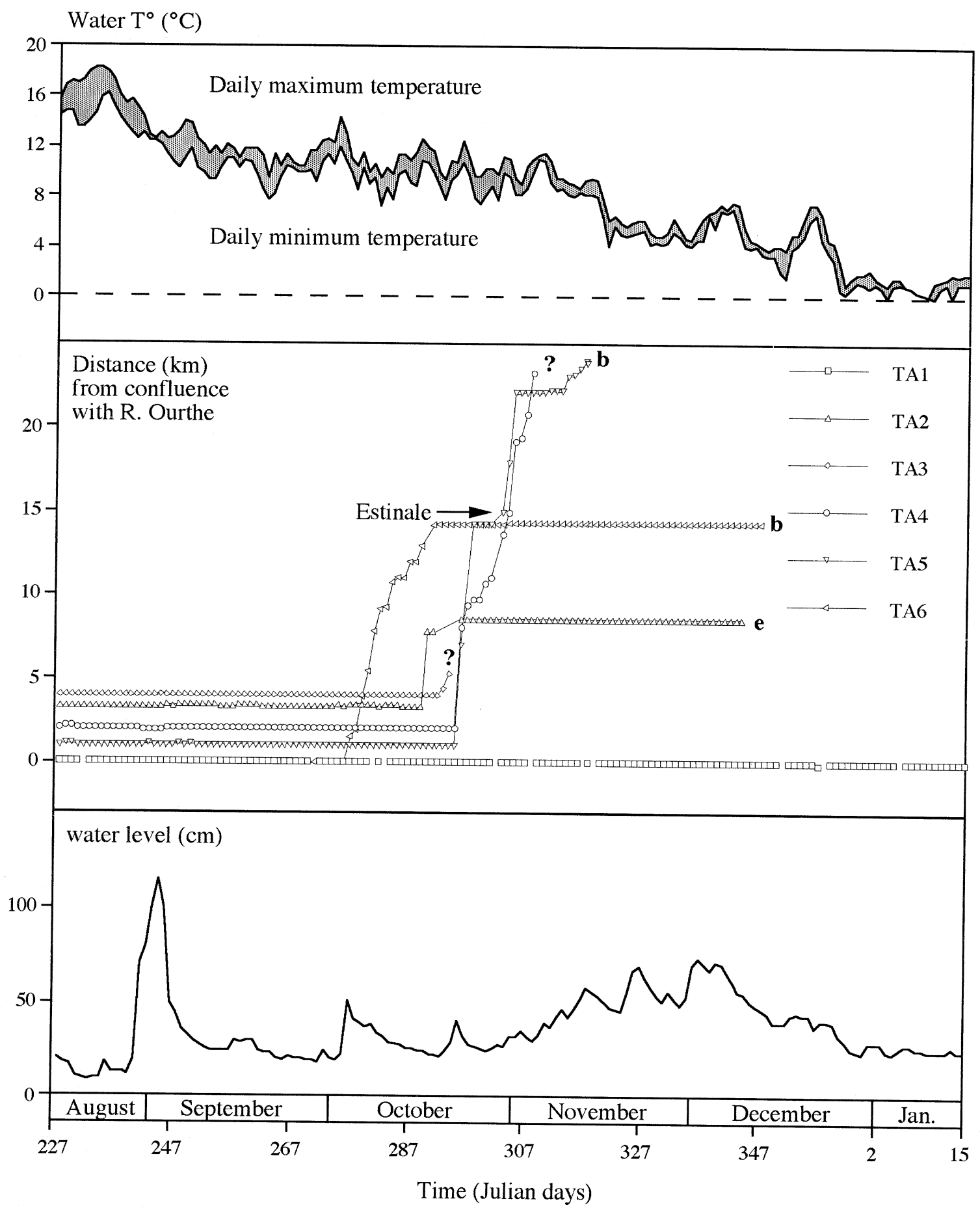

Figure 2. Daily variations of water temperature $\left({ }^{\circ} \mathrm{C}\right.$ ) and water level in the Aisne stream, from 14 August 1996 (JD 227) to 15 January 1997 (JD 15). Symbols on the central graph are positions of radio-tagged trout in the stream, with the confluence with the River Ourthe sited at $0 \mathrm{~km}$. b: end of the transmitter battery life, ?: fish lost; e: expulsion of the transmitter. 
$\mathrm{T}^{\circ}\left({ }^{\circ} \mathrm{C}^{\circ}\right)$

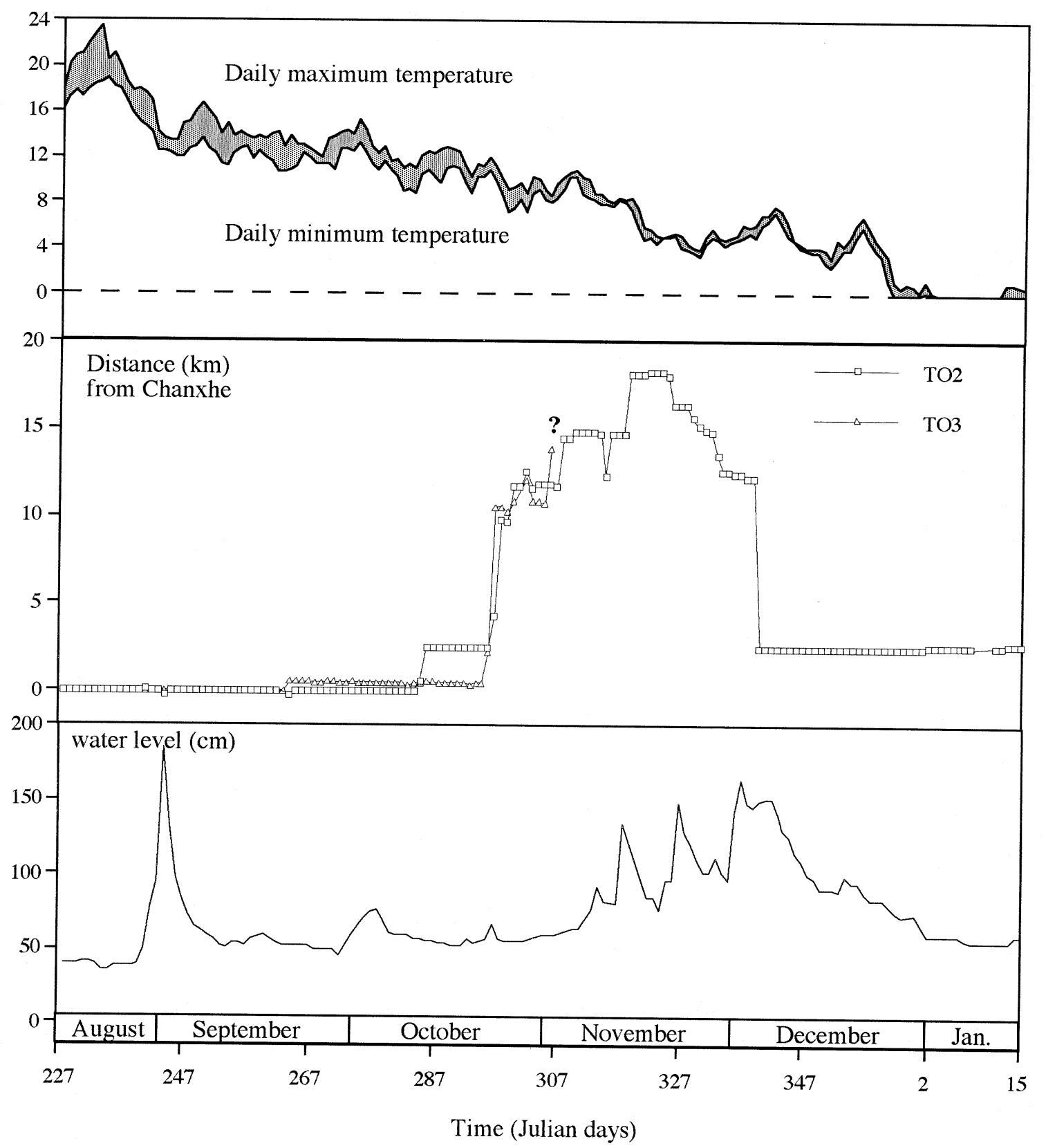

Figure 3. Daily variations of water temperature $\left({ }^{\circ} \mathrm{C}\right.$ ) and water level in River Ourthe, from 14 August 1996 (JD 227 ) to 15 January 1997 (JD 15). Symbols on the central graph are positions of radio-tagged trout in the River Ourthe, with the dam of Chanxhe sited at $0 \mathrm{~km}$. ?: fish lost. 
Table 2. Mobility of trout in the Aisne stream (A) and River Ourthe (B) depending on water temperature $\left(\mathrm{WT}^{\circ}\right)$, variations of water temperature $\left(\Delta \mathrm{WT}^{\circ}\right)$ and of water level $(\Delta \mathrm{WL})$ between consecutive days, regardless of the sense of the variation (decrease or increase). Trout TA1 and TO1, which made no migration, were excluded from the analyses. Values are means ( \pm standard deviation) of the length of net daily journeys (m) over $\mathrm{N}$ observations. The values sharing at least one common upperscript (a or b) do not differ at the 0.05 level of significance (Scheffe $F$-tests)

\begin{tabular}{lccrcc}
\hline $\mathrm{A}$ & & $\Delta \mathrm{WL}>5 \mathrm{~cm}$ & $N$ & $\Delta \mathrm{WL}<5 \mathrm{~cm}$ & $N$ \\
\hline $\mathrm{WT}^{\circ}>12{ }^{\circ} \mathrm{C}$ & $\Delta \mathrm{WT}^{\circ}>1^{\circ} \mathrm{C}$ & $6.7( \pm 6.7)^{\mathrm{a}}$ & 3 & $7.0( \pm 11.4)^{\mathrm{a}}$ & 10 \\
& $\Delta \mathrm{WT}^{\circ} \leq 1^{\circ} \mathrm{C}$ & $21.5( \pm 6.9)^{\mathrm{a}}$ & 24 & $8.1( \pm 5.0)^{\mathrm{a}}$ & 27 \\
$10^{\circ} \mathrm{C} \leq \mathrm{WT}^{\circ} \leq 12{ }^{\circ} \mathrm{C}$ & $\Delta \mathrm{WT}^{\circ}>1{ }^{\circ} \mathrm{C}$ & $1587.1( \pm 591.0)^{\mathrm{b}}$ & 15 & $442.5( \pm 282.0)^{\mathrm{a}}$ & 26 \\
& $\Delta \mathrm{WT}^{\circ} \leq 1^{\circ} \mathrm{C}$ & $11.6( \pm 3.2)^{\mathrm{a}}$ & 21 & $39.1( \pm 21.3)^{\mathrm{a}}$ & 78 \\
$\mathrm{WT}^{\circ}<10^{\circ} \mathrm{C}$ & $\Delta \mathrm{WT}^{\circ}>1{ }^{\circ} \mathrm{C}$ & - & 0 & $284.1( \pm 129.2)^{\mathrm{a}}$ & 24 \\
& $\Delta \mathrm{WT}^{\circ} \leq 1^{\circ} \mathrm{C}$ & $215.0( \pm 215.0)^{\mathrm{a}}$ & 2 & $331.4( \pm 122.8)^{\mathrm{a}}$ & 31
\end{tabular}

3-Way ANOVA: probabilities not calculated due to incomplete matrix

\begin{tabular}{|c|c|c|c|c|c|}
\hline B & & $\Delta \mathrm{WL}>5 \mathrm{~cm}$ & $N$ & $\Delta \mathrm{WL}<5 \mathrm{~cm}$ & $N$ \\
\hline \multirow[t]{2}{*}{$\mathrm{WT}^{\circ}>12^{\circ} \mathrm{C}$} & $\Delta \mathrm{WT}^{\circ}>1{ }^{\circ} \mathrm{C}$ & $0.7( \pm 0.7)^{\mathrm{a}}$ & 3 & $8.3( \pm 3.9)^{\mathrm{a}}$ & 9 \\
\hline & $\Delta \mathrm{WT}^{\circ} \leq 1^{\circ} \mathrm{C}$ & $39.9( \pm 16.7)^{\mathrm{a}}$ & 17 & $15.4( \pm 6.4)^{\mathrm{a}}$ & 31 \\
\hline \multirow{2}{*}{$10^{\circ} \mathrm{C} \leq \mathrm{WT}^{\circ} \leq 12{ }^{\circ} \mathrm{C}$} & $\Delta \mathrm{WT}^{\circ}>1{ }^{\circ} \mathrm{C}$ & $3887.5( \pm 1850.7)^{\mathrm{b}}$ & 4 & $138.3( \pm 95.8)^{\mathrm{a}}$ & 6 \\
\hline & $\Delta \mathrm{WT}^{\circ} \leq 1{ }^{\circ} \mathrm{C}$ & $20.0( \pm 28.3)^{\mathrm{a}}$ & 2 & $146.2( \pm 79.4)^{\mathrm{a}}$ & 32 \\
\hline \multirow[t]{2}{*}{$\mathrm{WT}^{\circ}<10^{\circ} \mathrm{C}$} & $\Delta \mathrm{WT}^{\circ}>1^{\circ} \mathrm{C}$ & $1403.6( \pm 1379.0)^{\mathrm{a}, \mathrm{b}}$ & 7 & $243.8( \pm 155.1)^{\mathrm{a}}$ & 8 \\
\hline & $\Delta \mathrm{WT}^{\circ} \leq 1^{\circ} \mathrm{C}$ & $350.2( \pm 141.3)^{\mathrm{a}}$ & 30 & $492.4( \pm 164.4)^{\mathrm{a}}$ & 31 \\
\hline \multicolumn{6}{|c|}{ 3-Way ANOVA: $\mathrm{WT}^{\circ}(\mathrm{A}): P=0.0024 ; \Delta \mathrm{WT}^{\circ}(\mathrm{B}): P=0.009 ; \Delta \mathrm{WL}(\mathrm{C}): P=0.008$} \\
\hline \multicolumn{6}{|c|}{ Interactions: A-B: $P=0.006$; A-C: $P=0.0142$; B-C: $P=0.0002$; A-B-C: $P=0.0074$} \\
\hline
\end{tabular}

TO3 was lost after it had migrated over $15 \mathrm{~km}$ in 11 days and was never recovered, despite intensive tracking surveys over more than $60 \mathrm{~km}$. TO2 went further upstream and entered the Lambrée stream on 13 November, when the water level in the River Ourthe increased by more than $50 \mathrm{~cm}$ and temperature dropped to less than $6.0^{\circ} \mathrm{C}$. On 16 November it moved to a gravel redd $250 \mathrm{~m}$ upstream where it remained for three days but could not be observed spawning, due to high turbidity and water level. On 20 November, it left the tributary, then progressively migrated down to the dam of Chanxhe. The corresponding rates of upstream migration were 741 and $1364 \mathrm{~m} \mathrm{~d}^{-1}$ (1537 and $2470 \mathrm{BL} \mathrm{d}^{-1}$ ), for TO2 and TO3, respectively. As in the Aisne stream, little activity was observed during daytime and most movement presumably took place at night. The longest upstream net daily journeys of TO2 and TO3 were 5500 and $8260 \mathrm{~m}$, respectively. Considering a mean nocturnal duration of 14 hours in mid-October and a mean water velocity of 0.5 to $0.7 \mathrm{~m}$ $\mathrm{s}^{-1}$ in the River Ourthe, these journeys would have been made at swimming speeds from 1.21 to $1.67 \mathrm{BL}$ $\mathrm{s}^{-1}$, thus at a similar speed as the trout in the Aisne stream. A 3-way ANOVA over the lengths of net daily journeys, using the same categories of environmental variables (water temperature, daily variations of water temperature and level) as in the River Aisne, revealed that trout of the River Ourthe travelled over significantly longer distances under highly variable water levels and fluctuating temperatures within the $10-12{ }^{\circ} \mathrm{C}$ range, than in any other set of environmental conditions (Table 2B). This compares with the situation observed in the Aisne stream, except for the distances, which were about twice longer in the River Ourthe. Similarly, the day when TO3 and TO2 made their first long journey (22 October), was the first day when this set of environmental conditions was observed under decreasing day length in the River Ourthe. 


\section{Discussion}

This study provided evidence that the migratory behaviour of trout in Belgian waters was ruled by precise environmental conditions. The chance that the tagging procedure or presence of the transmitter would have interfered with fish behaviour can not systematically be excluded based on healing dynamics (see Baras et al., 1998), but is presumably at a minimum as all fish had been tagged several weeks or months before they started their migration. Furthermore, we used extremely low transmitter to body weight ratios comparatively to other studies and these are most unlikely to have impaired the swimming capacity of the fish. Two fish eventually lost their intraperitoneally implanted transmitter in the latest stage of their migration, possibly because these transmitters, which were relatively small units, were expelled at the same time as the eggs.

During summer and early spring, when water temperature was above $12{ }^{\circ} \mathrm{C}$, no or few journeys were observed and mainly corresponded to routine home range movements or changes of residence within the same daily activity area. Similar short range summer movements of brown trout, in comparison with autumn mobility, have already been described in other telemetry studies (Clapp et al., 1990; Meyers et al., 1992; Young, 1994). Some trout showed higher mobility at the time when they were displaced by high floods but eventually homed under lower water level. This observation suggests that their low mobility during summer reflects their attachment to a precise residence. This may be interpreted within the context of optimal foraging strategies in a territorial species (Bachman, 1984; Hart, 1986), especially within a thermal range (12$16^{\circ} \mathrm{C}$ ) which is considered as optimal for trout growth (Elliott, 1975). At a time of the year which permits fast growth and energetic investment into reproductive products, trout would presumably gain advantage by remaining in an environment which they have experienced and recognised as suitable than by exploring new patches of which the quality is uncertain.

Although no observation of spawning activity could be made due to high and turbid waters, it can be reasonably assumed that autumn migrations were related to reproduction. In this study, all trout migrating during autumn moved upstream and two of them entered sub-tributaries. Except for some studies which documented downstream migrations of spawners (e.g. Oncorhynchus clarki Richardson, Brown \& Mackay, 1995), this finding is consistent with the abundant literature on trout spawning runs (Solomon \& Templeton, 1976; Harcup et al., 1984; Baglinière et al., 1987, Jonsson, 1991). Beyond the availability of suitable physical habitat features, the reason why trout move upstream is still debated. Upstream movements by spawners may compensate the natural drift of alevins with rising waters in spring (Margalef, 1963). A complementary hypothesis refers to the effect of high floods on spawning redds. High water levels and velocities interfere with the digging of spawning pits by salmonids (Baglinière et al., 1979), and high sediment loads affect the permeability of gravel beds, making them less suitable for the embryonic development (Tappel \& Bjornn, 1983). It is generally admitted that, due to their geomorphology, upper streams undergo much more intense but shorter variations of water level than lower streams and rivers. During periods of naturally high waters, such as late autumn and early winter, upstream spawners may thus find suitable conditions to spawn and for their eggs to develop, much more easily than downstream migrants.

The seasonality of trout spawning runs has been abundantly documented in various ecosystems (Jensen, 1968; Euzenat \& Fournel, 1976; Solomon \& Templeton, 1976; Baglinière et al., 1979, 1989; Jonsson, 1985; Euzenat et al., 1991; Maisse \& Baglinière, 1991; Meyers et al., 1992; Evans, 1994; Young, 1994; Arnekleiv \& Krabol, 1996; Marmulla \& Ingendahl, 1996). The final ascent of spawning tributaries and sub-tributaries is known to take place in autumn, with spawning from late autumn to mid winter, consistently with the findings that their gonads only undergo the final maturation stage under decreasing photoperiod (Billard et al., 1982; Breton et al., 1983). Within this migration period, environmental variables such as temperature, flow and their variations have been shown to influence the movements of winter spawning trout (Salmo trutta) and of spring spawning trout (cutthroat trout Oncorhynchus clarki). It has been known for some time that the initial spawning movements of cutthroat trout are stimulated by increased flows (Rayner, 1942; Johnson, 1963; Allan, 1978; Brown \& Mackay, 1995). Similarly, Baglinière et al. (1987) provided evidence that the spawning runs of brown trout in French rivers are conditioned by the timing of high floods. More recently, Ovidio et al. (1996) documented that flow was a major factor allowing spawners, blocked in the downstream reaches of dams and weirs which could not be cleared at low flow, to move. However, the influence of flow alone is still debated. Evans (1994) observed considerable move- 
ments of brown trout under low flow. Baglinière et al. (1987), Whelan et al. (1988) and Jonsson (1991) identified water temperature as an important factor in triggering, enhancing or inhibiting trout movement. Clapp et al. (1990) suggested that brown trout were migrating in response to seasonal changes of temperature. Meyers et al. (1992) indicated that rising temperature more than water levels was influencing the spring migration of brown trout.

This study clearly showed that it is a combination of factors, rather than a single variable, which triggered and enhanced the spawning runs of brown trout. Both in the River Ourthe and in the Aisne stream, trout started moving and travelled the longest distances when both flow and temperature varied considerably between consecutive days, within a precise thermal range $\left(10-12{ }^{\circ} \mathrm{C}\right)$. From an ecological point of view, these two factors may be regarded as cues of that the environment becomes unpredictable and/or hazardous, as its variability increases within a thermal range which is below the optimum, and no longer enables trout to achieve high growth rates (Elliott, 1975). This interpretation completes the aforementioned hypothesis on the restricted mobility of brown trout during summer. A suitable and stable environment would favour the resident behaviour of trout, whilst high or increasing environmental unpredictability would presumably cause them to trade off reproduction versus feeding and growth. This is consistent with the theory and findings on life-history strategies in teleost fishes, which increase their reproductive effort per unit of time when the environment becomes hazardous (e.g. Baras, 1995; synthesis in Wootton, 1990). Our analyses further pinpoint that a single cue of unpredictability is not enough to trigger trout migration, although this is not really surprising from a functional point of view. As rivers and streams are naturally variable environments, each of the three subsets, the combination of which triggers migration, happens on several occasions at different times of the year, including in summer (e.g. summer spate in August 1996 documented in this paper). Trout responding to a single environmental cue would thus start migrating earlier in the season and would lose a part of the energetic advantage provided by the summer sit and wait strategy, that could prove detrimental to their fitness at the time they would participate to spawning. An additional cue of environmental unpredictability could be the income of early migrants, that locally increase the population density in a reach. However, the hypothesis of a density-dependent migration pressure still is spec- ulative without additional information on the variation of population structure along time, which could not be collected at the time of the study as catch efforts probably would have strongly interfered with the genuine mobility pattern of radio-tagged fish.

This study provided new insights on the way trout adapt their behaviour and mobility pattern to environmental variations, which could have hardly been achieved without positioning the fish each and every day. Most tracking studies which provided contrasted results on the environmental cues triggering trout migration relied on the use of automatic listening stations (e.g. Marmulla \& Ingendahl, 1996) or on a much looser positioning frequency by mobile tracking: once a month (Young, 1994), once every two weeks (Clapp et al., 1990; Meyers et al., 1992), once a week (Økland et al., 1996), twice a week (Meyers et al., 1992; Young, 1994), once every two days (Brown \& Mackay, 1995). As the determinant cues documented in this study referred to variations between consecutive days, their influence could have hardly be revealed by these studies. The only study which provided detailed, day-by-day, information on the spawning runs of brown trout came from Evans (1994). However, it only documented the final days of the spawning migration and gave no information on their triggering.

The day-by-day positioning in this study also permitted to provide much more detailed information on the home range, migration pattern, extension of net daily journeys and on the swimming speeds which were presumably achieved by the trout. Trout in the River Ourthe and Aisne stream made seasonal upstream migrations ranging from 5.60 to $22.95 \mathrm{~km}$, with a mean upstream progression rate ranging from 0.74 to $1.56 \mathrm{~km} \mathrm{~d}^{-1}$. Long autumn migrations of brown trout are not surprising since Jensen (1968) and Jonsson (1985) provided evidence that brown trout could travel over more than $100 \mathrm{~km}$. Our results compare with those of Clapp et al. (1990) who reported that five of six trout in a Michigan stream travelled over more than $10 \mathrm{~km}$ during autumn, with a maximum of $22.73 \mathrm{~km}$ in two weeks $\left(1.62 \mathrm{~km} \mathrm{~d}^{-1}\right)$. Marmulla and Ingendahl (1996) documented migration rates of sea trout up to $3.30-4.00 \mathrm{~km} \mathrm{~d}^{-1}$, over three to four days. This exceeds the mean rate of our trout but compares with some parts of their migration as we observed that four fish made net daily journeys longer than $5 \mathrm{~km}$ $\mathrm{d}^{-1}$. Not surprisingly, we detected very little migratory activity during daytime (two occasions) and all long range movements of trout in autumn were made at night. This finding goes along with the observa- 
tions by Clapp et al. (1990) and by Heggenes et al. (1993), who reported that brown trout tended to become highly nocturnal during winter. The migration pattern of trout in the Aisne stream and River Ourthe resembled a log curve: the daily journeys were longer or more frequent in the first days of the migration than when the fish came closer to its presumed spawning place. Meyers et al. (1992) also found that the migration of trout in Northern Wisconsin slowed down in its second part. Evans (1994), who focused on the migratory behaviour of trout in their spawning tributary, on their last days of ascent, reported no upstream progression rate higher than $2 \mathrm{~km} \mathrm{~d}^{-1}$. The reason for reduced migration speeds at the end of the ascent may refer to lower temperatures, higher floods or search for spawning redds, but remains to be investigated.

Contrary to the findings by Young (1994), we found no major difference between the distances travelled by fish of different size in the River Ourthe and Aisne stream, neither for the mean upstream progression rates nor for the maximum length of net daily journeys. This indicates that small trout in the Aisne stream travelled over longer distances comparatively to their body length than larger fish in the River Ourthe. However, when the mean water velocity, relative to fish length, was added to the progression rate, we found that the presumed mean swimming speeds during long journeys in the two rivers were quite close (2.42 and 1.67 $\mathrm{BL} \mathrm{s}^{-1}$, respectively). Furthermore, the maximum swimming speed in the Aisne stream compares with the maximum record in the River Ourthe, which was documented in a previous study (Ovidio et al., 1998): a $489 \mathrm{~mm}$ trout made a nocturnal upstream migration over $15 \mathrm{~km}$ in late December 1995 $(8 \mathrm{~L}-16 \mathrm{~N})$, at a time of the year when the water velocity averaged $1 \mathrm{~m} \mathrm{~s}^{-1}$ in the river, corresponding to an upstream progression rate of $0.53 \mathrm{BL} \mathrm{s}^{-1}$ and an estimated swimming speed of $2.57 \mathrm{BL} \mathrm{s}^{-1}$. These swimming speed estimates compare with the maximum sustained speeds over long periods, documented in the literature on salmonid swimming (e.g. O. nerka: $2.8 \mathrm{BL} \mathrm{s}^{-1}$ over $10 \mathrm{~h}$ at $10^{\circ} \mathrm{C}$; Brett, 1964). This comparison suggests that trout move as fast and as far as they possibly can (limitations by day-night alternation and swimming speed) during their early migration days. As swimming speed basically depends on water temperature, early fast movements may prove an energetically advantageous solution for long range migrations.

\section{Conclusion}

This study provided evidence that the spawning migration of trout in Belgian waters is triggered by environmental unpredictability, which causes the fish to abandon a sit and wait strategy and to move as fast as possible to their spawning places, under water temperatures which still permit fast swimming speeds. The consistency of the results in the two rivers supports the idea that spawning migration of trout in the River Ourthe sub-basin is well focused, despite the probable heterogeneity of the fish stock. It should be noted however that some fish living in the downstream reaches of dams and weirs did not migrate at all in 1996. The meaning of this hyper-resident behaviour still remains to be investigated.

All data were collected during a single year and demand further confirmation. The strong synchrony in the spawning migrations does not permit to determine to what extent the combination of environmental variables which triggered the migration of trout in 1996 was accidental. In any case, it is obvious that results and interpretations would have definitely been different with a positioning frequency less than once a day. Looser sampling would have made us unable to understand how trout adapt to their environment, and as a corollary, how they would presumably react to a natural or man-made modification of their environment. These often represent major shortcomings of models and should be considered in future studies. From a management point of view, this study suggests that any hydraulic work which buffers the variability of the environment may suppress key cues for trout migration, delay their migration and possibly impact on their reproductive success and populations.

\section{Acknowledgements}

M. Ovidio received a Ph.D. research grant from FRIA ('Fonds pour la Formation à la Recherche dans l'Industrie et dans l'Agriculture') for a project on the behavioural ecology of trout. This research is part of the 'Meuse Saumon 2000' project, which is supported by the Ministry of Environment (D.G.R.N.E) of the Walloon Government. The authors wish to thank G. Rimbaud for field support and M. Blaude, who kindly permitted us to access his private properties when tracking trout. J. C. Philippart is a research associate of the Belgian FNRS. 


\section{References}

Allan J. D., 1978. Trout predation and the size composition of stream drift. Limno. Oceanog. 23: 1231-1237.

Arnekleiv, J. V. \& M. Krabol, 1996. The effects of induced floods on the upsteam migration of adult brown trout, and the effects of water release on the postspawning downstream migration in a regulated Norwegian River. In E. Baras \& J. C. Philippart (eds), Underwater Biotelemetry, Proceedings of the first conference and workshop on fish telemetry in Europe, University of Liège, Belgium: 172.

Bachman R. A., 1984. Foraging of free ranging wild and hatchery brown trout in a stream. Trans. am. Fish. Soc. 113: 1-32.

Baglinière, J. L., A. Champigneulle \& A. Nihouarn, 1979. Le frai du saumon atlantique (Salmo salar) et de la truite commune (Salmo trutta) sur le bassin du Scorff. Cybium. 3: 75-96.

Baglinière, J. L., G. Maisse, P. Y. Le Bail \& E. Prevost, 1987. Dynamique de la population de truite commune (Salmo trutta L.) d'un ruisseau breton (France) - les géniteurs migrants. Acta oecol., oecol. Appl. 8: 201-215.

Baglinière, J. L., G. Maisse, P. Y. Lebail \& A. Nihouarn, 1989. Population dynamics of brown trout (Salmo trutta L.) in a tributary in Brittany (France): spawning and juveniles. J. Fish Biol. 34: 97-110.

Baras, E., 1995. Thermal related variations of seasonal and daily spawning periodicity in Barbus barbus. J. Fish Biol. 46: 915917.

Baras, E., C. Birtles, L. Westerloppe, X. Thoreau, M. Ovidio, D. Jeandrain \& J. C. Philippart, 1998. A critical review of surgery techniques for implanting telemetry devices into the body cavity of fish. In Y. Le Maho (ed.), Proceedings of the 5th European Conference on Wildlife Telemetry. Strasbourg, France, 26-30 August 1996: 10 pp.

Billard, R., A. Fostier, C. Weil \& B. Breton, 1982. Endocrine control of spermatogenesis in teleost fish. Can. J. Fish. aquat. Sci. 39: 65-79.

Birtles, C., E. Baras, P. Poncin, G. Goessens \& J. C. Philippart, 1995. A behavioural and histological assessment of post-tagging stress in brown trout Salmo trutta L. equipped with surgically implanted biotelemetry transmitters. In: Abstracts of the second Benelux congress of zoology. University of Leiden, The Netherlands: 95.

Breton, B., A. Fostier, Y. Zohar, P. Y. Le Bail \& R. Billard, 1983. Gonadotropine glycoprotéique maturante et oestradiol-17 B pendant le cycle reproducteur chez la truite fario (Salmo trutta) femelle. Gen. Comp. Endocrinol. 49: 220-231.

Brett, J. R., 1964. The respiratory metabolism and swimming performance of young sockeye salmon. J. Fish. Res. Bd Can. 21: 1183-1226.

Brown, R. S. \& C. Mackay, 1995. Spawning ecology of cutthroat trout (Oncorhynchus clarki) in the Ram River, Alberta. Can. J. Fish. aquat. Sci. 52: 983-992.

Clapp, D. F., R. D. Clark \& J. S. Diana, 1990. Range, activity and habitat of large, free-ranging brown trout in a Michigan Stream. Trans am. Fish. Soc. 119: 1022-1034.

Elliot, J. M., 1975. The growth rate of brown trout (Salmo trutta L.) fed on maximum ration. J anim. Ecol. 44: 805-821.

Euzenat, G. \& F. Fournel, 1976. Recherche sur la truite commune (Salmo trutta L.) dans une rivière de Bretagne, le Scorff. Thèse de troisième cycle Biol. Anim. Univ Rennes 1, 213 pp.

Euzenat, G., F. Fournel \& A. Richard, 1991. La truite de mer en Normandie-Picardie. In J. L. Baglinière \& G. Maisse (eds), La truite: biologie et écologie. INRA Editions, Paris: 183-213.
Evans, D. M., 1994. Observations on the spawning behaviour of male and femele adult sea trout, Salmo trutta L., using radiotelemetry. Fish. Mgmt Ecol. 1: 91-105.

Faush, K. D. \& M. K. Young, 1995. Evolutionary significant units and movement of resident stream fishes: A cautionary tale. Am. Fish. Soc. Symp. 17: 360-370.

Gowan, C., M. K. Young, K. D. Fausch \& S. C. Riley,. 1994. Restricted movements in resident stream salmonids: a paradigm lost. Can. J. Fish. aquat. Sci. 51: 2626-2637.

Harcup, M. F., R. Williams \& D. M. Ellis, 1984. Movements of brown trout, Salmo trutta L., in the River Gwyddon, South Wales. J. Fish Biol. 24: 415-426.

Hart, P. J. B., 1986. Foraging in teleost fishes. In T. J. Pitcher (ed.), The Behaviour of Teleost Fishes. Croom Helm, London: 211235 .

Heggenes, J., O. M. W. Krog, O. R. Lindas, J. G. Dokk \& T. Bremnes, 1993. Homeostatic behavioural responses in a changing environment: brown trout (Salmo trutta) become nocturnal during winter. J. anim. Ecol. 62: 295-308.

Hesthagen, T., 1988. Movements of brown trout, Salmo trutta, and juvenile Atlantic salmon, Salmo salar, in a costal stream in northern Norway. J. Fish Biol. 32: 639-653.

Jensen, K. W., 1968. Sea trout (Salmo trutta L.) of the river Istra, western Norway. Rep. Inst. Freshwat. Drottningholm 48: 187213.

Johnson, H. E., 1963. Observations on the life history and movement of cutthroat trout, Salmo clarki, in Flathead River drainage, Montana. Proc. Mont. Acad. Sci. 23: 96-110.

Jonsson, B., 1985. Life history patterns of freshwater resident and sea-run migrant brown trout in Norway. Trans. am. Fish. Soc. 114: 182-194.

Jonsson, N., 1991. Influence of water flow, water temperature and light on fish migration in rivers. Nordic J. Freshwat. Res. 66: 20-35.

Leclerc, M., H. Capra, S. Valentin, A. Boudreault \& Y. Coté (eds), 1996. Proceedings of the Second IAHR Symposium on Habitat Hydraulics, Ecohydraulics 2000, published by INRS-Eau, Québec (Canada), Vol. A: 893 pp, Vol. B: 995 pp.

Maisse, G. \& J. L. Baglinière, 1991. Biologie de la truite commune (Salmo trutta). In J. L. Baglinière \& G. Maisse (eds), La truite: biologie et écologie. INRA, Versailles, France: 25-45.

Marmulla, G. \& D. Ingendahl, 1996. Preliminary results of a radio telemetry study of returning Atlantic salmon (Salmo salar L.) and sea trout (Salmo trutta trutta L.) in River Sieg, tributary of River Rhine in Germany. In E. Baras \& J.C. Philippart (eds.), Underwater Biotelemetry, Proceedings of the First Conference and Workshop on Fish Telemetry in Europe, University of Liège, Belgium: 109-117.

Margalef, R., 1963. On certain unifying principles in ecology. Am. Naturalist 97: 357-374.

Meyers, L. S., T. F. Thuemler \& G. W. Kornely, 1992. Seasonal movements of brown trout in Northeast Wisconsin. N. am. J. Fish. Mgmt 12: 433-441.

Økland, F., J. A. Jensen \& B. O. Johnsen, 1996. Winter habitat and seaward migration of a Norwegian brown trout population. In E. Baras \& J. C. Philippart (eds), Underwater Biotelemetry, Proceedings of the First Conference and Workshop on Fish Telemetry in Europe, University of Liège, Belgium: 161-171.

Ovidio, M., C. Birtles, E. Baras \& J. C. Philippart, 1996. A preliminary telemetry investigation on the obstacles to anadromous Salmonids migration in spawning streams of the Belgian Ardennes (river Meuse basin). In M. Leclerc et al. (eds), Ecohydraulics 2000, Proceedings of the Second IAHR Symposium on Habitat Hydraulics. INRS-Eau, Vol A: 83-88. 
Ovidio, M., C. Birtles, E. Baras, J. C. Philippart \& F. Giroux, ???? Daily and seasonal movements of radio-tagged brown trout (Salmo trutta) in the Belgian Ardennes: mobility versus residency. In Y. Le Maho (ed.), Proceedings of the Fifth European Conference on Wildlife Telemetry in Europe. Strasbourg (France), 25-30 August 1996: in press, 6 pp (in press).

Philippart, J. C., 1987. Histoire de l'extinction et de la problématique de la restauration des salmonidés migrateurs dans la Meuse. In M. Thibault et R. Billard (eds), La restauration des rivières à saumons, INRA, Paris, France: 125-137.

Philippart, J. C., A. Gillet \& J. C. Micha, 1988. Fish and their environment in large European river ecosystems. The River Meuse. Sciences de l'Eau 7: 115-154.

Philippart, J. C., J. C. Micha, E. Baras, C. Prignon, A. Gillet \& S. Joris, 1994. The Belgian project 'Meuse Salmon 2000'. First results, problems and future prospects. Water Sci. Technol. 29: 315-317.

Philippart, J. C. \& E. Baras, 1996. Comparaison of tagging and tracking studies to estimate mobility patterns and home range in Barbus barbus. In E. Baras \& J. C. Philippart (eds), Underwater
Biotelemetry, Proceedings of the First Conference and Workshop on Fish Telemetry in Europe, University of Liège, Belgium: 312.

Rayner, H. J., 1942. The spawning migration of rainbow trout at Skaneatles Lake, New York. Trans. am. Fish. Soc. 71: 180-183.

Shetter, D. S., 1968. Observations on movements of wild trout in two Michigan streams drainage. Trans. am. Fish. Soc. 97: 472480 .

Solomon, D. J. \& R. G. Templeton, 1976. Movements of brown trout in a chalk stream. J. Fish Biol. 9: 411-423.

Tappel, P. D. \& T. C. Bjornn, 1983. A new method of relating size of spawning gravel to salmonid embryo survival. N. am. J. Fish. Mgmt 3: 123-135.

Whelan, G. E., S. Marod \& W. W. Taylor, 1988. Fisheries Report, E.L.F. communications system ecological monitoring program. U.S. Navy Electronics Systems Command, Technical Report E06548-8, washington, D.C.

Wootton, R. J., 1990. Ecology of Teleost Fishes. Chapman \& Hall, London: $392 \mathrm{pp}$.

Young, M. K., 1994. Mobility of brown trout in south-central Wyoming streams. Can. J. Zool. 72. 2078-2083. 